\title{
Dis-positioning Euthyphro
}

\author{
Ben Page $^{1}$ (D)
}

Received: 11 January 2017/ Accepted: 15 May 2017

(C) The Author(s) 2017. This article is an open access publication

\begin{abstract}
The Euthyphro objection is often perceived, rightly or wrongly, as the king objection to theistic meta-ethics. This paper proposes a response that hasn't been much explored within the contemporary literature, based on the metaphysics of dispositions and natural law theory. The paper will first contend that there is a parallel between ways theists conceptualise God's role in creating laws of nature and the ways God creates goods. Drawing upon these parallels I propose a possible response to the dilemma, where this response parallels the dispositionalist response as to how God creates laws of nature. I do this by first explicating a natural law theory of goodness, then suggesting how the ontology of dispositions can be used in a novel way to account for goods, and finally by explaining how all this relates to the dilemma. I conclude the paper by posing some objections to myself and providing some replies.
\end{abstract}

Keywords Euthyphro dilemma - Natural law · Dispositions · Laws of nature · Divine command theory

The Euthyphro dilemma has remained within the arsenal of those objecting to a theistic grounding of ethics until the present day. Pigliucci, for example, thinks 'the most convincing reason why gods cannot possibly have anything to do with

\begin{abstract}
An earlier version of this paper was presented at the Tyndale fellowship for Philosophy of Religion study group at the University of Cambridge in 2015, and benefitted from their helpful comments. I also wish to thank Tim Mawson, Martin Smith, Martin Pickup, Anna Marmodoro, and Ralph Walker who provided insightful feedback on an earlier draft.
\end{abstract}

Ben Page

ben.page@stcatz.ox.ac.uk

1 St Catherine's College, University of Oxford, Manor Road, Oxford OX1 3UJ, UK 
morality was presented 24 centuries ago by Plato, in the ...Euthyphro dialogue'. ${ }^{1}$ We might therefore characterise the Euthyphro objection as perceived as the king objection to theistic meta-ethics. This paper will propose a response that hasn't been explored much within the contemporary literature, after first contending that there is a parallel between ways theists conceptualise God's role in creating laws of nature and ways God creates goods. Drawing upon these parallels I propose a possible response to the dilemma, where this response parallels the dispositionalist response as to how God creates laws of nature. I do this by first explicating a natural law theory of goodness, then suggesting how the ontology of dispositions can be used in a novel way to account for goods, and finally by explaining how this all relates to the dilemma. I conclude the paper by posing some objections to myself and providing some replies.

Before beginning, allow me to explain the perspective that this paper will take. My goal will be to provide the background and framework of an as of yet unexplored, at least in contemporary work, response to the Euthyphro dilemma. Since this response draws together many different elements of modern metaphysics and ethics, and asks us to reimagine how we might usually conceive of God's relation to goodness, I will take a big picture approach in the paper (and won't be able, for reasons of space, to give an account of its detailed contours). As a result, this paper alone won't accommodate all the aspects of this view worthy of thorough examination. Yet this shouldn't be thought detrimental, since a major goal of the paper is to encourage further more detailed work in this area, through capturing the interest of my audience, with this perhaps culminating in an alternative research programme in contemporary theistic meta-ethics, and exploration of its diverse implications. In virtue of this, at times I will reference other scholars and articles which undertake much background work, provide additional argumentation, and offer possible avenues for answering questions that one might ask about this view, which due to the constraints of the paper I am unable to elaborate further on. I hope to also explore some of these areas in greater detail at a later date.

\section{The Euthyphro dilemma}

The Euthyphro dilemma first appears in Plato when Socrates asks Euthyphro, 'Is the pious loved by the gods because it is pious, or is it pious because it is loved by the gods?' Contemporary discussions, however, have adjusted the dilemma in three ways. First, by accommodating the prevalent western monotheism, second, in being concerned with God's 'commands' rather than his 'loves', and third, through posing the dilemma in terms of the 'the right' or 'the good' rather than piety. Thus some formulate the dilemma as asking whether God commands $X$ because it is right/ obligatory, or whether $X$ is right/obligatory because God commands it, ${ }^{2}$ whilst others ask whether God commands $Y$ because it is good, or if $Y$ is good because God

\footnotetext{
1 Pigliucci (2013, vol. 37, p. 150).

2 Swinburne (2016, p. 224), Mackie (1982, pp. 114-115), Wierenga (1989, pp. 213-215), Brink (2007, p. 151), Quinn (2006, pp. 73-74), Grayling (2013, p. 51), Ruse (2015, p. 164).
} 
commands it, ${ }^{3}$ and yet others ask both. ${ }^{4}$ The dilemma facing theists is that by taking one horn what is right or good is no longer dependent on God's commands but becomes independent of him, resulting in God's actions being determined by something outside himself, thereby removing his aseity. However, the other horn forces theists to say that rightness or goodness is arbitrarily dependent on God's commands, such that God could make stealing a right action or murder a good.

\section{Rightness and goodness}

Some have sought to answer the Euthyphro objection through drawing a distinction between rightness and goodness or deontology and axiology respectively. ${ }^{5}$ The distinction holds that some actions are good and yet not right/obligatory. For instance, it would be good to become a doctor, but it might not be right/obligatory since you already have a profession that pays for your family's wellbeing, that you enjoy, that is already good for society, etc. Armed with this distinction the Euthyphro dilemma can be answered in terms of rightness, since one can hold that God is good in virtue of a different conception of goodness, and that He commands what is right because $\mathrm{He}$ is good. ${ }^{6}$ This might satisfy those that formulate the Euthyphro dilemma in terms of rightness, but clearly not those who formulate it in terms of goodness. Unless sufficient reasons are given why the goodness formulation of the dilemma is inappropriate, the Euthyphro objection comes back to bite.

Given this, my account will seek to answer the Euthyphro argument in terms of goodness, which I take to be more fundamental than rights/obligations. Evans seems to agree with this sentiment since he allows that there may be reasons other than God's commands, which determine rights/obligations, for not doing something, namely because it is bad. He writes, 'Even apart from God's command, stealing would then be bad and humans would have reasons not to steal. ${ }^{, 7}$ Thus one might adopt my approach for questions concerning the Euthyphro dilemma in terms of goodness (axiology), and another approach concerning the Euthyphro dilemma as formulated in terms of rightness/obligations (deontology). However, if one thinks it possible to question the distinction between rightness/obligations and goodness, since perhaps one thinks all rights/obligations can be derived from goods, ${ }^{8}$ then my response alone will be sufficient for answering both types of Euthyphro objection. Nonetheless, since disputing this distinction is highly controversial I will continue

\footnotetext{
3 Antony (2009, pp. 71-72), Davies (2004, p. 273), Stump (2010, p. 304), Copan (2013, p. 92), Ward (2013, p. 104), Craig (2008, p. 181), Harris (2011, p. 14).

4 Oppy (2006, p. 354, n. 6), Zagzebski (2005, p. 359), Mann (2015, p. 316).

5 Evans (2013, p. 26), Baggett and Walls (2011, p. 47), Millken (2009, pp. 151-152).

${ }^{6}$ Evans thinks divine command theory deals with rightness, but presupposes a distinct theory of goodness: Evans (2013, p. 54).

7 Evans (2013, p. 35).

${ }^{8}$ For attempts see: Oderberg (2000, pp. 53-63), Feser (2015, pp. 331-348), Murphy (2011, pp. 70-74).
} 
as though I am only answering the Euthyphro dilemma in terms of goodness (axiology). ${ }^{9}$

\section{God and laws of nature ${ }^{10}$}

I propose that parallels can be drawn between ways God can create laws of nature, and ways He can create goods. To demonstrate this I will show how theists conceptualise God's creative relationship with laws of nature, and then illustrate how these parallel His creating goods. I will then suggest one parallel is currently neglected as a response to the Euthyphro dilemma, but given developments in contemporary metaphysics and ethics, should be further explored.

Contemporary metaphysics and philosophy of science broadly think about the ontology of laws of nature in one of three ways, Humeanism, strong external governing laws (SEG), and dispositionalism. The Humean regularity view, on a traditional reading of Hume, takes laws to be descriptions of what regularly happens, where laws have no ontological status, and therefore Humeanism might be thought of as anti-realist concerning laws. The SEG view is associated with DretskeTooley-Armstrong, ${ }^{11}$ where laws are necessary connections between universals, and the antireductionist views of Carroll and Lange, ${ }^{12}$ where universals are not required. ${ }^{13}$ On this account laws are items within our ontology, being connections between universals/tropes, for instance where the universal/trope 'water' might be connected with 'freezes at $0{ }^{\circ} \mathrm{C}$ '. Importantly this view holds that laws have a sui generis necessity, 'intermediate between Humean contingency and necessity, which we might call "nomic necessity". ${ }^{14}$ The reason for this is that it is suggested that we can imagine a world where all the non-nomic facts are the same but the laws are different. Thus, in world $\mathrm{W} 1$, the non-nomic facts, $F$, plus the laws, L1, cause $X$ to move up, but in world $\mathrm{W} 2$, where the non-nomic facts are identical, $F$, but the laws are different, L2, $X$ would move down. Laws on this view are therefore external to the substances they govern, since what determines how substances behave is not internal to the substances themselves rather you have passive substances and laws that act upon them. ${ }^{15}$

The third option is the dispositionalist position, ${ }^{16}$ which has increased exponentially in popularity over the last few years. On this view dispositions are properties that have their causal role essentially, where one reason for thinking this

\footnotetext{
9 One can easily combine my account of goodness with a different account of rights/obligations, for example with a divine command theory of rights/obligations: Evans (2013).

${ }^{10}$ I provide an extended discussion of this topic elsewhere: Page (2015).

11 Armstrong (2010, pp. 35-47).

12 Carroll (1994), Lange (2000).

13 Anti-reductionists are less explicit about 'nomic-necessity', however they think laws are metaphysically contingent and have the same modal implications as the Dretske-Tooley-Armstrong account.

14 Armstrong (2010, p. 41).

15 I use substances as synonymous with 'things' or 'beings'.

${ }^{16}$ Ellis (2001), Bird (2007).
} 
is from thinking a property's identity is best accounted for by its causal role. ${ }^{17}$ This directly contrasts SEG theorists since their thought experiment appeared to show that the same property could act causally in different ways. SEG therefore requires quidditism, where each property has some primitive identity, thereby enabling it to have diverse causal roles across possible worlds. By contrast dispositionalists suppose that causal role is fixed across all possible worlds, and as a result can be thought to adopt a type of property essentialism, where what is essential to a property across all possible worlds is its causal role. ${ }^{18}$ Laws on this view, come included with properties, since once you have properties you have all you need for laws of nature. Substances on this view are therefore not passive, moved by active external laws, but rather internally active and dynamic. ${ }^{19}$

Given this brief summary, how should theists conceptualise God's creating physical laws? On the anti-realist/Humean view, God creates substances free of connections, since laws are merely descriptions of the regularities we observe. God therefore creates in one step since He only instantiates substances. A second possible view, not previously discussed since I know of no one who holds it, might conceptualise physical laws as necessary, existing independently from God, perhaps as Platonic forms. On this picture, God creates substances governed by pre-existent laws. Here, as with the previous view, God creates in one step since laws are necessarily existent and the only creative work required is in supplying passive substances. Laws on this view are external to substances since they exist independently of substances, and consequently one could have laws without substances or identical laws with different substances.

On SEG God creates substances and then laws to govern them, or laws and then substances to be governed by them. Substances on this conception are essentially passive whilst the laws, however construed, are active. Importantly laws, paralleling the Platonic view, are external to substances since they can exist without substances, or substances exist without laws, or different laws exist with different substances, or identical substances exist with different laws, or identical laws exist with different substances. However, unlike the Platonic view God creates in two steps since He creates two ontological entities, substances and laws.

Finally, for the dispositionalist, when God creates He gets two for one, since by creating substances with dispositional properties He also instantiates laws of nature, since causal role is essential to these properties. For instance, negative charge essentially has the power to repel other substances with negative charge, and thus once this property is created so too is the law that negative charge repels negative charge without any further ontological work needed. Laws are therefore internal to the substances they govern, and thus God creates in one step, creating substances with properties. God still determines which laws are instantiated since $\mathrm{He}$

\footnotetext{
17 Shoemaker (1980).

18 I use essence throughout as referring to 'definitional' or 'serious' essence: Fine (1994), Lowe (2008).

19 It is difficult to adequately classify the dispositionalist view since a number of differing positions are advocated. Ellis holds that laws are reduced to dispositions, Bird and Molnar take it that laws supervene on dispositions, and Mumford thinks dispositions eliminate laws altogether. What is clear is that dispositions play a primary role and laws are in some sense dependent on them. Ellis (2001), Bird (2007, p. 202), Molnar (2003, p. 199), Mumford (2004).
} 
determines the properties created, but once these properties exist the laws are fixed and cannot be changed.

\section{How God creates goods}

How then do these creative acts concerning laws of nature parallel how God creates goods? ${ }^{20}$

Starting with the anti-realist/Humean view of physical laws, I suggest the moral parallel be anti-realism regarding the ontological status of goods. In virtue of this anti-realism God does no ontological work in creating goods other than creating substances, since we humans determine the goods. This parallels God's role in creating laws of nature, where He makes substances with no connections and we spot regularities. The Euthyphro dilemma, given this anti-realism concerning goodness, doesn't have any bite against the theist, yet since the majority of theists are moral realists they will reject this position.

The Platonic view of physical laws parallels a Platonic view of goodness, where goods are necessary existents, existing eternally and being distinct from God. God therefore only creates substances since goods are pre-determined by eternal moral propositions. Goodness is therefore external to substances, paralleling the Platonic view of physical laws, since God could create different substances or none at all and yet the nature of goodness still exist and remain the same. This position responds to the Euthyphro dilemma by conceding that goodness is distinct from God, thereby making it less arbitrarily dependent upon God's commands. However, the theist must concede that God lacks aseity on this view since there are existents independent of him. ${ }^{21}$ Adopting this horn of the dilemma is one theists should embrace as a last resort, as theists should seek to defend the traditional view of God as a perfect being who does not depend on anything else, if possible.

The SEG view, I suggest, parallels the horn of the Euthyphro dilemma that has goodness dependent on God's commands, Divine Command Theory (DCT). Just as with physical laws, where God can create a world where water (substance) boils at 100 degrees (law) and another world where identical water (substance) boils at 200 degrees (law), or any other temperature, so too in the moral sphere God can create one world where $Y$ (law) is good for $X$ (substance) but another world where, $Y$ (law)

\footnotetext{
${ }^{20}$ This approach was thought up independently of Murphy who also draws similar parallels between morality and laws of nature, however our accounts vary in distinct ways: I make more distinctions, focus more on ontology, and emphasise different implications. Nonetheless, Murphy's book is instructive in further thinking about these parallels and my work here can be thought of as proposing an amendment/ addition to elements of his work. Murphy (2011, pp. 14-44).

21 Perhaps it is not aseity per se that is the conflict here but a corollary of it, sovereignty. I therefore understand my objection against the Platonist to be that they cannot hold what Gould calls the aseitysovereignty doctrine AD: (i) God does not depend on anything distinct from Himself for his existing, and (ii) everything distinct from God depends on God's create activity for its existing.' Craig and Leftow make similar points in their work on the topic. This accusation also depends upon one's application of $\mathrm{AD}$, since if it is merely defined as applying to substances/concreta, and then goods are taken to be abstract, then there appear to be no difficulties. Yet many in contemporary literature think abstracta pose a risk to God too. Gould (2014, pp. 1-2), Craig (2016, pp. 1-2), Leftow (2012, pp. 1-28).
} 
would be evil for $X$ (substance), and $Z$ (law) be good. On this view goodness is external to substances and therefore, as in the physical realm, God creates in two steps, creating laws/goods and then substances, or substances and then laws/goods.

The dispositionalist equivalent, ${ }^{22}$ I contend, is the least explored amongst contemporary responses to the Euthyphro dilemma, where the moral parallel is traditional natural law theory. ${ }^{23}$ On this view the ends of substances determine goods, just as physical laws are determined by the dispositional properties of substances. God creates/instantiates laws of nature in one step through creating substances with dispositional properties, and likewise God creates/instantiates goods through creating substances with natural ends, since a substance's goods are the fulfilment of its natural ends. Further, both views have the governing role internal to substances, meaning that without substances you wouldn't have laws/goods, and that you can't have the same substances with different laws/goods.

However, one might worry that there is an unsavoury parallel here with the Platonic account since God is bound by the essential behaviour of properties, and this might cause aseity worries. I think this concern is misplaced since the worry with the Platonists was that there were entities existing a se apart from God that explained goodness such that God couldn't change the type of goodness in the world. However, on the natural law account, goodness is set by definitional essences which exist, on one view, as concepts within God's mind and are just true by definition. ${ }^{24}$ Being true by definition, these definitional essences are broadly logically or metaphysically necessary, ${ }^{25}$ and theists usually do not think these types of propositions are ones that limit God's aseity or omnipotence, particularly since these definitions may well depend upon God, thorough being grounded in the divine intellect. The aseity worry therefore, should only be of concern if one thinks God can do what is broadly logically or metaphysically impossible, something most theists don't accept. The dispositionalist position thus has no entities distinct from God, and yet God still has the prerogative as to which properties He creates, that is instantiates in the world, ${ }^{26}$ and therefore what distinct goods the world has. I will spell out further details of this account later, however all I currently wish to show are the parallels between God's creating laws of nature and goods.

A response to the dilemma I have neglected to comment on thus far is reliant upon the doctrine of divine simplicity. ${ }^{27}$ This solution may be fruitful but many

\footnotetext{
${ }^{22}$ Murphy purposefully conflates this position with SEG: Murphy (2011, pp. 33-34). Here are two quick reasons to think these positions distinct. Firstly they require different ontologies, SEG requires quiddities whereas dispositionalism doesn't. Secondly some dispositionalists, e.g. Mumford, think their view eliminates laws, but it is difficult to see how this is possible on SEG. Mumford (2004).

23 As opposed to the new natural law theory: Grisez (1996), Finnis (2011), George (1999).

24 These definitional dispositional essences could exist as divine concepts, either as universalsScholastic realism, or nominalistically-Theistic concept-nominalism. Peterson (1999), Leftow (2006).

25 Fine (2005, p. 236).

26 This at least seems to be the Aristotelian sense of creating properties. If this is still unclear then we can say that by creation I mean that God creates the natural version of these properties, where these are grounded in God's mind as divine ideas.
}

27 Kretzmann (1999), Stump (2003, pp. 127-128). 
theists today think simplicity indefensible, ${ }^{28}$ thereby rejecting what has been termed the classical theist conception of God. ${ }^{29}$ Instead, numerous theists have embraced theistic personalism ${ }^{30}$ or monopolytheism, ${ }^{31}$ the view that personhood is the basis from which God should be conceptualised, ${ }^{32}$ with some claiming that since we are persons we can in some sense conceive what it would be like to be God in some respects. ${ }^{33}$ Classical theists strongly disagree, arguing that even though God possesses personal attributes, e.g. intellect and will, we should not conceptualise God based on our personhood, due to making Him too anthropomorphic, but rather upon His being metaphysically ultimate. ${ }^{34}$ I have nothing to say here about this debate, and will comment no further on the simplicity option but raise it for the sake of completeness. ${ }^{35}$ However, I note here that the two solutions I take to provide the best answers to the dilemma, DCT and natural law theory, both appear compatible with simplicity or its rejection, and therefore theistic personalists and classical theists can adopt either solution.

Before discussing my positive proposal further, I wish to explore the parallel between SEG and DCT in a little greater detail to provide further reasons for thinking that dispositionalism is a distinct position from SEG, contra Murphy, ${ }^{36}$ and therefore give a different moral parallel. I also hope to show that the concerns many have over SEG and DCT are extremely similar, with both being answered in the same way by the dispositionalist and natural law view. ${ }^{37}$

\section{Divine command theory (DCT)}

DCT in its simplest form holds that goodness is determined by God's commands, thereby taking the horn of the dilemma where God's commands determine goods. ${ }^{38}$ Within contemporary work it is by far the most extensively explored research programme of theistic meta-ethics, with current attention focused upon which aspect of God grounds moral facts, commands being the traditional view, but recent proposals instead suggesting God's intentions, desires, emotions, or

\footnotetext{
28 Plantinga (1980).

29 Davies (2004, pp. 2-9).

30 Davies (2004, pp. 9-14).

31 Hart (2013, p. 127).

32 Swinburne (2016, p. 1).

33 Swinburne (2016, p. 114).

34 Leftow even goes so far as to assert that 'the kind deity is plausibly not a highest kind, an ontological category, but rather a sub-kind of person'. This is something classical theists would most likely deny. Leftow (2012, p. 301).

35 I should note that there have been a number of recent defenses of simplicity, for instance: Dolezal (2011), Brower (2008).

36 See note 22.

37 This will become clearer during the extended discussion of natural law.

38 It should be noted that most DCT'ists have given up trying to root moral goodness in divine commands, and instead now only employ DCT for rights/obligations and an alternative approach for goodness.
} 
attitudes. ${ }^{39}$ The benefits and drawbacks of these differing proposals do not concern me here; rather I wish to highlight a similarity between SEG and all conceptions of divine command/intention/desire/emotion/attitude theory.

The SEG conception of laws allows that one can have exactly the same substances but different laws governing them, with this said to count in its favour. ${ }^{40}$ This means God can create substances wholly independent of laws, and therefore exact replica worlds where all the substances are the same but the laws different. It also implies that God can create laws and then decide to create no substances to be governed by them, or substances with no laws to be governed by. Due to the sui generis modality needed on this conception to connect universals/tropes, SEG requires quidditism, which holds that each property has its own primitive identity. However, many reject quiddities due to their sceptical implications that stems from completely divorcing what a property can do from its nature. ${ }^{41}$

DCT parallels this within the moral realm by suggesting we could have worlds with exactly the same substances and yet completely different goods, again requiring an intermediate sui generis necessity. ${ }^{42}$ Just as with quiddities where God can arbitrarily command what a substance/property does since it can possibly do anything, in the moral realm God can arbitrarily command what the goods of substances are since possibly they can be anything. ${ }^{43}$ In fact God can even make the goods of one human different from another, since goods are not essentially linked to anything, and may therefore be individually linked to distinct haecceities. ${ }^{44}$ Many find this implication problematic, both in the case concerning laws of nature and moral goods, where the problematic element arises from divorcing the nature of a property or substance from its causal role or goods. Regarding physical laws the property/substance does nothing to determine what laws it obeys, and in the moral realm the nature of the property/substance does nothing to determine its goods.

This above concern is at the heart of the arbitrariness worry against DCT, however some have claimed this complaint can be adverted through holding that God is essentially good and therefore cannot command anything evil. Firstly, it should be noted that this response does nothing to answer the worry that different individuals or species could have radically different goods than they in fact do have, even if these goods are not evil. However, at a more general level it seems to raise the problem as to what certain predications relating to God mean. When we say that "God is good", given DCT's conception of goodness, all we would seem to mean is that God does whatever He commands. Koons goes further, arguing this solution

\footnotetext{
39 Murphy (1998), Quinn (2001), Miller (2009), Zagzebski (2004), Jordan (2013).

${ }^{40}$ For criticism of this thought experiment see: Beebee (2000), Loewer (1996).

41 Black (2000), Bird (2007, pp. 66-98), Chakravartty (2017).

42 Murphy calls this moral necessitation, and continually uses the language of moral selection. Murphy (2011, pp. 35-37).

43 Some DCT's will protest by arguing that God cannot command the goods of some $x$ to be anything, since they will suggest there are restrictions even upon him. This may well be the case, yet even if God cannot command the goods of an $x$ to be anything, he could still have commanded it to be innumerably other things than it in fact is.

44 Haecceities are much like quiddities in the previous paragraph, only that haecceities relate to substances whereas quiddities relate to properties.
} 
saddles defenders "with a notion of divine goodness that is empty of content. ${ }^{45}$ Idziak responds to this type of objection stating that calling God good only expresses 'a favourable emotional attitude towards God' ${ }^{46}$ I do not here wish to assess this line of argument, its responses, and other complex and subtle debates concerning DCT. It may well be the case that satisfactory answers can be given to these and other problems raised against DCT. ${ }^{47}$ Rather all I wish to accomplish here through alluding to these potential difficulties is to firstly provide some motivation for contemporary exploration of a different research programme within theistic meta-ethics, and secondly to show how the response I lay out below overcomes the worries above. With that said it is time to turn to my positive proposal.

\section{Natural law}

Recent work within metaphysics and ethics has made traditional natural law theory more tenable and I now sketch it out more fully. However, I do not here intend to defend the natural law theory of goodness, a task too ambitious for this paper, but rather I present it to show how theists can employ it to answer the dilemma. ${ }^{48}$ Obviously, if one rejects this conception of goodness then my proposed response fails and one must adopt another answer. However, since this theory of goodness is gaining popularity, and is a plausible candidate for being the correct conception, it is beneficial to investigate how theists may employ it. Further, if this conception of goodness provides the best response to Euthyphro dilemma this affords theists an additional reason to adopt this view of goodness over others.

In his Nicomachean Ethics, Aristotle writes, 'Every art and every enquiry, and similarly every action and pursuit, is thought to aim at some good; and for this reason the good has rightly been declared to be that at which all things aim. ${ }^{49}$ This conception of goodness has made a comeback within modern philosophy, primarily due to the work of Geach and Foot. ${ }^{50}$ A core idea is that 'there is no such thing as being just good or bad, there is only being a good or bad so-and-so.' ${ }^{51}$ That is good and bad are made only in reference to specific functions of substances, and therefore what is good for $X$ 's may not be good for $Y$ 's. Teichmann thus writes, 'In 'a good F', the concept ' $F$ ' will involve some sort of goal, or function, or role, or characteristic mode; hence being a good doctor, or a good parent, or a good neighbour, is a matter of doing what can reasonably be expected of a person with that goal, or function, or role, or characteristic mode. ${ }^{52}$ Metaphysically this conception holds that substances

\footnotetext{
45 Koons (2012, p. 188).

46 Idziak (2004, p. 311), Adams (1987, pp. 113-116).

47 For a nice introductory overview see: Miller (2013).

48 Recent defenses: Alexander (2012), Oderberg (forthcoming), Almotahari and Hosein (2015).

49 Aristotle. Nicomachean ethics. Book 1, Part 1.

50 Geach (1956), Foot (2001).

51 Geach (1956, p. 33).

52 Teichmann (2011, p. 89).
} 
have essences, ${ }^{53}$ and that their natural appetites or ends are determined by a substance's essence, with the fulfilment of those ends being its good, resulting in the substance's flourishing. Foot puts it this way writing, "natural' goodness, as I define it, ... is intrinsic or 'autonomous' goodness in that it depends directly on the relation of an individual to the 'life form' of its species. ${ }^{54}$ Further, this conception of goodness is not limited to persons, ${ }^{55}$ as Chappell notes, 'goods are not, or not essentially, aspects of human flourishing. What they are essentially is this: they are the ideal standards that apply in the different normative dimensions. Things can be worse or better in ever so many different ways; and the variety of goods corresponds to that variety. ${ }^{56}$ I will assume this theory of goodness for the remainder of this paper and follow Oderberg's definition of the good as 'that which satisfies a thing's natural appetites, or that which fulfils a thing's nature. ${ }^{, 57}$

Since this view holds that the natural appetites contained in a substance's essence determine the goods of a substance, we can see a parallel with the dispositionalist view of physical laws. As explained earlier, God's creating dispositional properties automatically instantiates laws of nature, and likewise when God creates appetites/ ends of substances, He creates the goods of substances, since the goods of substances are the fulfilment of their natural appetites/ends. Further, paralleling the dispositionalist account of laws, God gets two for the price of one, since through creating dispositions He gets physical laws, and likewise by creating a substance's essence with natural appetites/ends $\mathrm{He}$ gets the goods of substances at no extra ontological cost.

A problematic feature of DCT was that God could create the same substances but with different goods, due to a sui generis necessity, thereby making the goods of a substance seemingly arbitrary and changeable. However, for the conception of goodness under investigation this is not the case, with the parallel dispositionalist account of physical laws proving insightful as to why. For dispositionalists, negative charge essentially repels other substances with negative charge, and God cannot change what negative charge does, but can only create a new property. Thus, if negative charge no longer repelled negative charge but instead attracted negative charge then the property would no longer be negative charge. Likewise, God cannot make a plant, which already has an essence with natural ends and therefore certain goods, have totally different goods. It cannot once have been good for a plant to take in water but now bad, and instead ingesting chicken becoming a good for it. The only way God could make this the case would be by destroying the plant's essence and creating a new essence of something that looked like a plant but now flourished by consuming chicken. ${ }^{58}$ Since goods are set by the natural appetites/ends of a substance's essence, God cannot change the goods without changing the essence of

\footnotetext{
53 Or at least one way of metaphysically spelling out this view.

54 Foot (2001, pp. 26-27).

55 Linking goodness with being makes it easier to see how different types of substances can be called good, for attempts see: Feser (2014b), Oderberg (2014), MacDonald (1991).

56 Chappell (2004, p. 108).

57 Oderberg (2000, p. 37).

58 But how similar they are is debatable.
} 
a substance. This means, that just as with laws of nature where once you have the same properties across all possible worlds you also have the same physical laws, once you have the same natural appetites/ends of substances across possible worlds you also have the same goods.

Given what has just been said we must answer another potential question, whether God could make a substance with an essence extremely similar to humans, such that they appear indistinguishable from one another, and yet it have goods different from humans. I will call this possible essence a Schuman, and the response to this will have to be no, at least to a significant extent. It is important to see that this question has the same intuition behind it as the SEG thought experiment, that we can have the same properties with different laws, but as we have seen this is something the dispositionalist view, of which natural law is the moral parallel, denies. Changes in the essence of a substance, will entail changes in the natural appetites/ends of that substance, which therefore will entail changes in the goods of that substance. Seemingly changing the essence slightly might only change the natural appetites/ends slightly, thus only changing the goods slightly, whereas changing the essence drastically, will change the natural appetites/ends drastically, and hence the goods drastically. One might protest to the effect that we can imagine the scenario sketched above, a Schuman essence with different goods, where this protestation parallels the SEG theorist's response to those who think their thought experiment a metaphysical impossibility. The reply to both, however, will be the same, that it may well be imaginable but it is nonetheless metaphysically impossible, and we should heed the continual cautionary advice that imaginability is not a good guide to possibility. ${ }^{59}$ Some might think this quite a bullet to bite, where what turns out to be possible is radically reduced, both concerning laws of nature and goods, given definitional essences, but this is a bullet that many happily bite within law of nature debates due to thinking SEG rests on poor metaphysics, and I suggest to the extent one is willing to bite it there one should also be willing to bite it here.

However, perhaps we can give an alternative reply to this question, where the answer depends upon what the essence of a human is. Traditionally the essence of a human has been thought of as a 'rational animal', and here I assume this definition. Given this, some have gone so far as to suggest that aliens, who have a different biological structure but also rationality and animality, should be thought of as possessing a human essence. ${ }^{60}$ Thus a Schuman, if it were to have a different essence, would need to be a being that had a different type of rationality. However, its plausible to think that rationality has a necessary and holistic structure, such that a different rationality is impossible. Further, theists think God is perfectly rational, and therefore God cannot determine what rationality entails since it is part of his nature. Human rationality therefore resembles God's perfect rationality. Schumans, then, would only seem to differ from humans in having a different biological structure, rather than a different rational animal essence. Given this, and since it is a

\footnotetext{
59 I discuss in more detail some of the problems and replies dispositionalists can give relating to imaginability and possibility elsewhere: Page (forthcoming).

60 Oderberg (2007, pp. 103-105), Hacker (2007, p. 313).
} 
claim of many natural law theorists that the ends of rationality determine many or most human goods, the majority of goods Schumans have will not differ from humans. The only place where Schumans goods may differ will be those goods concerning biology, since presumably to be distinct from humans Schumans will have a different biological makeup and hence flourishing, just as humans and fish have different biological goods given their different biological makeup. However, there are likely limits as to how Schumans can attain these different bodily goods, since the ends of rationality will play a key role here, e.g. through not killing other rational animals, etc.

To summarise then, God on this view, although unable to change definitional essences since they are broadly logically necessary, still determines the moral structure of the world as He determines which essences are instantiated. God has a range of options over what worlds He can create, given these truths, and freely chooses which natural properties to create. ${ }^{61}$ We should only be worried about this limiting God's freedom, or removing His aseity, if we are also concerned that broadly logically necessary truths limit God's omnipotence, and given that most theists don't think this constraint is problematic I contend we should think the same concerning the natural law account of goods. Further, on this account although God freely decides which goods are instantiated in the world, He cannot freely determine what the goods for each substance's essence are, since these are determined by the natural appetites/ends of the definitional essence. Thus, something good cannot become evil for a substance and equally something evil cannot become good. Goodness, on this account, is therefore to some extent dependent on God, yet also dependent upon the natural appetites/ends of a substance's essence, since the fulfilment of these determine the goods of the substance.

\section{Dispositioning natural law}

Adding to my positive proposal, I suggest we can further parallel laws of nature and the moral realm through a novel use of dispositions as a basis for goodness. ${ }^{62}$ Dispositions have as of yet been neglected within most contemporary ethical thought, ${ }^{63}$ however through employing an essential aspect of them, their directedness towards their manifestation, we can make use of them within our ethical theory. Some dispositionalists have characterised this inherent directedness in terms of 'physical' or 'natural intentionality', ${ }^{64}$ whilst another suggests we think of it as a

\footnotetext{
61 This seems similar to a Molinist view of creation.

62 Perhaps only some dispositions are morally-relevant whilst others are not, e.g. a human's disposition for happiness, might be morally-relevant, whereas an electron's disposition to repel other electrons be morally-irrelevant. Alternatively, there may be no strong distinction here if goodness can be spelled out in terms of being (note 55). Yet for the purpose of this paper it is simpler to assume two types of dispositions.

63 Where they are discussed dispositions are used in distinct ways from how I employ them, and don't touch upon the meta-ethics of goodness: Anjum et al. (2013), Smith et al. (1989), Robinson (2011).

64 Molnar uses 'physical intentionality', Heil uses 'natural intentionality', Martin, Place and Armstrong use intentionality. Molnar (2003, pp. 60-81), Heil (2003, p. 221), Martin (2007, p. 178), Place (1996).
} 
type of normativity. ${ }^{65}$ Yet others prefer the traditional language of Aristotle's final causality, ${ }^{66}$ partly due to objections raised against the parallel between mental and physical intentionality, ${ }^{67}$ although this has recently been defended from some criticism. $^{68}$

With this apparatus, we can modify our account of goodness since in its basic form we are taking goodness to be the fulfilment of a substance's appetite/end. Lisska provides an instructive outline in his treatment of Aquinas's natural law theory writing, 'the philosophical anthropology Aquinas adopts is based upon a metaphysical theory of essences, whose structure is composed of dispositional properties ... the end or 'telos' is the point at which the dispositional properties in the primary substance reach their development or perfection. ${ }^{69}$ Dispositions then are directed, or to use some unpopular jargon, teleologically structured, towards their end or manifestation. Since goodness is the fulfilment of an appetite/end, dispositions play a vital role in determining the goods of substances. If some substance, such as a plant, is disposed to grow when taking in water, then water is a good for it since it fulfils its end. If a hamster's eating chocolate causes it to become sick and unwell, chocolate is bad for it since it frustrates its combined dispositions to be healthy. It may be difficult to ascertain which dispositions a substance possesses and what is conducive to their fulfilment, an epistemological problem, but once we know what fulfils the dispositional properties we can know what the goods of a substance are. As Feser writes, "knowing what is truly good for us requires taking an external, objective, "third-person" point of view on ourselves rather than a subjective "first-person" view; it is a matter of determining what fulfils our nature, not our contingent desires. ${ }^{70}$ I don't suppose here to explain how one works out what the ends of dispositional properties are or how to identify the dispositions contained within a substance's essence, but rather only make the metaphysical point that goodness, on this conception, depends upon the fulfilment of dispositional properties.

Given all this we can say that God's creating dispositional properties instantiates laws of nature, due to a disposition's essential causal role, but also instantiates the goods of substances, due to a disposition's directedness or teleological structure. God therefore not only gets two for the price of one, but a real bargain and gets three!

How does all this relate to the Euthyphro dilemma? Theists can suggest that through creating/instantiating dispositional properties God determines what the goods of the world are, since He could have created dispositions other than those He has instantiated and hence other goods. Yet, since a disposition's essence is essentially directed toward its manifestation, God cannot make it the case that the created natural dispositions have a different end and thereby good, or that their

\footnotetext{
65 Lowe (1989, ch. 8).

66 Oderberg (2016), Feser (2014a, pp. 88-105), Kroll (2017).

67 Bird (2007, pp. 118-126), Oderberg (2016).

68 Bauer (2016).

69 Lisska (1996, p. 96).

${ }^{70}$ Feser (2014b, p. 87).
} 
current good have been always or becomes bad. In this sense, goodness isn't fully dependent on God since it depends upon the directedness of dispositions. Yet, we are able to bypass the worrying aspects of the Platonist horn since there are no objects existing independent of $\operatorname{God}^{71}$ and given that the definitional dispositional essences are broadly logically necessary they pose little risk to God's aseity and freedom. ${ }^{72}$ However we also avoid the worrying aspects of arbitrariness, since God cannot make it the case that any substance have any good, or to be more specific, that for substances like us murder or torture be good, since this is not conducive to human flourishing given our dispositional essences.

Nonetheless, we should note that this solution does leave us with some aspect of arbitrariness, since God could have endowed the world with a different structure of goodness through creating different dispositions, just in the same way He could have made different laws. Yet I take this type of arbitrariness to be benign, since it seems the usual concern over the Euthyphro dilemma's arbitrariness relates to the reasons God has for commanding us, that is substances of our kind, to do thus and so. For instance, Sinnott-Armstrong writes, 'Let's assume God commanded us not to rape. Did God have any reason to command this? If not, his command was arbitrary, and then it can't make anything morally wrong. ${ }^{73}$ On my view the prohibition to rape is not arbitrary since the reason this is evil is because it goes against our dispositional essence and hence our flourishing. Further, if my earlier comments are correct and rationality is essential to any substance like humans, and if the ends of rationality can rule rape to be an evil, rape can never be a good for any type of rational being. Thus, the only arbitrariness left on my account is not one concerning why $X$ is good for substances with essence $Y$, but rather why we have essences $Y$ rather than $Y_{1}$, and hence goods $X$ rather than $X_{1}$. The worry then, if there is one, amounts to the fact that certain goods and evils are missing or included in specific worlds due to there being or not being certain substances. There is no longer any worry that the goods or evils of these existing substances will change, since they can't, rather all we can now ask is why God didn't create certain alien kinds and hence their alien goods, or why He created the kinds He did. As to the reason why God created the substances He has and hence their necessary goods be instantiated, I don't suppose to have a comprehensive answer. Yet there is no longer any worry over God arbitrarily commanding and determining what the goods of things are. ${ }^{74}$

My view therefore says that there is a range of logically possible definitional dispositional essences that God can instantiate, and therefore create as natural properties, with God having the freedom to choose which He creates. Thus, it seems

\footnotetext{
71 I understand 'objects' to include propositions. 'Propositions, we shall say, are the sharable objects of the attitudes and the primary bearers of truth and falsity.' McGrath (Spring 2014 Edition).

72 Just as they pose little risk for those defending omnipotence.

73 Sinnott-Armstrong (2009, p. 108), Wielenberg (2013, p. 95).

74 On my view God could change the structure of goodness in the actual world but only by destroying all instances of a certain species since in virtue of that He eliminates the possibility of their goods, or by introducing an alien species and hence their necessary alien goods. But this doesn't worry me like the views where God can change the goods of a species whenever He commands and perhaps endow them different goods in different possible worlds, etc. These worries mirror some of those put against SEG and quidditism, and a further comparison here might be useful.
} 
to me the dispositionalist gets the best of both horns, where God to some extent determines the axiological structure of the world, whilst not also arbitrarily determining the goods of specific substances.

\section{Objections}

\section{Ontological baggage}

A significant objection to my response is the need for greater ontological commitment to undergird the theory. ${ }^{75}$ The metaphysics required, as we have seen, is one with God, substances, essences, and dispositions, whereas by contrast DCT presumably needs only God and substances with quiddities. We might be able to argue that essences are needed in DCT as well, since presumably when God issues commands He commands them for a type of substance, e.g. human beings rather than giraffes, and therefore the essence 'humankind' enables God's command to cover and apply to all humans. Nonetheless, plausibly if we said there was no such thing as the essence humankind God could still issue commands but would have to specify either a set of individuals as to whom the commands applied, e.g. the substances Laura, Derek, Carrie, Charlotte, Joshua, etc., or specify necessary and jointly sufficient properties for the kind human that His commands are directed towards. ${ }^{76}$ This way one might be able to remove the need for essences on a DCT and therefore plausibly only require two ontological items, God and substances with quiddities.

However, perhaps my view only requires God and dispositional properties, since substances could simply be bundles of properties and essences merely human constructs for categorisation. I am doubtful of this and nonetheless I am not much concerned by the perceived ontological baggage of substances, essences and dispositions since I would contend these items are needed for a robust ontology, although I will not be able to defend that claim here.

The worry instead might manifest itself in another guise, in that granted I think these items are needed for a robust ontology, this claim is nevertheless only supported by a few theorists. Put another way, the elements of Aristotelianism and Thomism that I am implicitly relying on are endorsed by very few today, and are consigned by many merely to history. It therefore turns out that in the end I am preaching to the choir in an otherwise empty church. My response to this concern is as follows; had this objection been raised a number of years ago, I might have conceded the point. Yes, the solution might have worked, as some Ancients and Medievals seemed to think, but time has moved and so too has our metaphysics. Yet since this objection is raised today I have no intention of conceding. In fact, ironically, it would appear that far be it that I am relying upon out-dated metaphysics for my solution, it is rather the objector that has not kept up to date

\footnotetext{
75 Pope (2012, p. 82), Ward (2013, pp. 73-74).

76 As we have seen DCT will likely require quiddities too, and these will be put to more ontological use if essences are removed.
} 
with many components of modern metaphysical theorising. For if they had they would be aware that over the last few years there has been an impressive resurgence of Aristotelian ${ }^{77}$ and Thomistic ${ }^{78}$ philosophy that is showing little sign of stopping.

Looking at each element individually, essences, as is well known, have made a storming comeback since the work of Kripke, Fine, and others. ${ }^{79}$ Dispositions/ powers, have also seen an impressive revival with their reduction into categorical properties being seen as extremely difficult if not impossible, and are now embraced non-reductively by many. ${ }^{80}$ Finally, teleology, although receiving the least attention of the three, has gained much traction within recent years as I have tried to demonstrate throughout the many references given in this paper. ${ }^{81}$ In fact it is this impressive revival and continual investigation of Neo-Aristotelian-Thomistic metaphysics that was a significant driving factor behind my writing this paper. The aim then has been to show that there are adequate resources today for a renewed appreciation of this approach, perhaps even providing the resources for the view I have spelled out broadly here to once again become a thriving research project within theistic meta-ethics.

\section{Teleology}

Another objection to this account might be the need of directedness/teleology for this conception of goodness. Many today baulk at such a view of nature, and therefore I must briefly do my best to make it palatable. ${ }^{82}$ First we ought to remember that, 'Teleology must be distinguished from design, ... Design is to be understood as conscious intent and artifice applied externally to the order of nature, in order to achieve some end or external goal; teleology [however] can be interpreted simply as evidence of function or purpose within nature, as an expression of natural laws and natural order. ${ }^{83}$ Building on this, we can classify levels of teleology into five categories ${ }^{84}$ : basic causal regularities, complex inorganic processes, ${ }^{85}$ basic biological phenomena, distinctive animal life, and in human thought and action. From this we can see that at its most basic level teleology explains why $X$ always does $Y$ rather than $T, U$, $V$, etc. It is therefore primarily a normative claim, and this is all the conception of goodness I am advocating requires. Those advocating natural or physical intentionality embrace

\footnotetext{
77 For instance: Tahko (2012), Groff and Greco (2013), Novotný and Novák (2014), Simpson et al. (2017).

78 For instance: Paterson and Pugh (2006), Haldane (2002), Brower (2014), Feser (2014a).

79 Work here is numerous, but here are some examples: Kripke (1972), Fine (1994), Oderberg (2001).

${ }^{80}$ The literature here has expanded exponentially, in recent years but some important works that I have not already cited are: Mumford (1998), Marmodoro (2010), Vetter (2015), Jacobs (2017).

81 References could be multiplied somewhat, but in particular see notes on page 16 and the discussion below.

82 Much work has recently been done regarding evolutionary related concerns of teleology and essentialism, for starters see: Walsh (2015), Walsh (2006).

83 McGrath (2011, p. 189).

84 Feser (2010, pp. 149-152).

85 Oderberg (2008).
} 
this level of teleology, and it can be argued that one is committed to this level of teleology if they hold to some ontologically realist view of laws of nature. ${ }^{86}$ Thus, in its basic form teleology should be stomachable. ${ }^{87}$

\section{Fact/value confusion}

A further objection might claim that I am confusing facts with values, where the facts of dispositions, shouldn't be confused with axiology or what is normatively the case. However, given the directionality inherent within the world this objection doesn't hold. An acorn when put in soil and watered is disposed to or directed towards growing, fulfilling its essence, and becoming an oak tree. It is naturally and internally directed towards becoming this rather than a daffodil, apple tree or some animal. Given this, goodness is not something extra added onto the fact of things, but 'is another way of referring to the completed state of the dispositional property in the individual. ${ }^{88}$ Thus, if the natural world has directionality it is not value free but value laden 'there is no way of describing the world accurately that omits natural normative teleology'. 89

\section{What do we mean by God's goodness?}

We might also ask of this account what is meant when we say 'God is good'? As I've emphasised we call something good when it fulfils its essence, or achieves its end and something bad when it fails to fulfil its essence. God is good because His essence is totally fulfilled, with nothing to be added, He is a fully flourished essence. We can make this clearer by following Davies who writes, "Aquinas always distinguishes between "perfect" and "good." On his account, a perfect $X$ lacks nothing that it could have in the way of attributes or properties fulfilling it (perfective of it), considered as what it is. ${ }^{90}$ God then, rather than being good is perfect in that He lacks nothing.

\section{Godless ethics}

A final objection that I will consider is 'the possibility of doing ethics without any reference to God, ${ }^{91}$ where my view might be thought to allow that there would be goodness even if God didn't exist. Now it is certainly true that on this account by ascertaining the ends of dispositional properties and essences one could come to know what the goods of substances are without divine commands. However, natural law theory in other ways initially seems as meta-ethically reliant upon God as DCT, since both require one act of creation, either the creation of dispositional properties

\footnotetext{
86 Hoffman (2009).

${ }^{87}$ For other interesting modern takes on teleology see: Hawthorne and Nolan (2006), Nagel (2012).

${ }^{88}$ Lisska (1996, p. 199).

${ }^{89}$ Oderberg (2010, p. 65).

90 Davies (2011, p. 33).

91 Original italics. Idziak (2004, p. 296), Murphy (2011, p. 74).
} 
or commands. Yet, there is an important difference here. Consider the entities distinct from God in the actual world and hold them fixed. On DCT, if God does not exist, then no commands have been issued and hence there is no goodness. But on natural law theory, if God does not exist then certain things are still good, due to the dispositional properties of things. Hence a different type of response needs to be given.

My suggestion is to go on the offensive and claim that natural law requires God to be more deeply and continually involved within the ethical realm than DCT. Since the natural world's teleological/directed structure is foundational to natural law, we could follow Aquinas's fifth way in arguing that an intelligence, God, is always needed to direct irrational substances towards their end. Natural law would therefore be more dependent on God than DCT, since DCT only needs God at the initial moment for his commands. But if God must continually direct irrational essences towards their ends then He plays an ontological role in natural law ethics at every moment. Obviously, this would require Aquinas's fifth way to be defended, and this paper makes no attempt to do so although there have been some recent attempts. ${ }^{92}$ However, if this is indefensible, one could instead claim that 'every good ... is a divine likeness', 93 where God is perfect goodness and the ends of dispositions resemble Him in some way.

Some however, have thought that goodness should have an even greater reliance on God, where this manifests as the thought that God should determine what the goods of substances are. It thus seems that the sui generis modal notion connecting universals/tropes for both laws of nature and goods is seen as virtuous, since it gives God the control to mix things up through selecting what goes with what. But as I have tried to show, this is no virtue, and instead leads to the problematic element of arbitrariness raised by the Euthyphro objection. On the dispositional picture, there isn't a question as to whether God could do this, since the ends of properties, and thereby their goods are contained within their definitional essence. Yet because of this we might ask, how do these definitional essences depend upon God? The traditional view, and one that fits well with my account, is what Welty calls Theistic conceptual realism which holds that these definitional essences 'are necessarily existing, uncreated divine ideas that are distinct from God and dependent on God.' 94 They thus depend upon God in that they 'exist eternally in the infinite divine intellect, as the archetypes according to which God creates the world.' 95 This type of approach would be considered a deity theory, where 'God's nature makes necessary truths true or gives rise to their truthmakers' ${ }^{96}$ However, if you don't like deity theories, then at least one other option seems open. ${ }^{97}$ All that is required for my response to the Euthyphro dilemma is a view that doesn't allow God to have been able to make different definitional essences or that the current one's be other

\footnotetext{
92 Feser (2013), Rooney (2013).

93 Murphy (2011, p. 160).

94 Welty (2014, p. 81).

95 Feser (2010, p. 146).

96 Leftow (2014, p. 435).

97 Leftow, for instance, has recently argued against deity theories in God and Necessity. Leftow (2012)
} 
than they are. Thus, one could adopt Leftow's proposal, ${ }^{98}$ which has it that God thinks up what 'secular states of affairs' there are in what he calls the Biggest Bang, where these 'secular states of affairs' include the definitional essences of properties. Nonetheless, as Leftow explains, 'while it is in God to have thought up different things than He has, there are no other things such that it is in God to have had a Bang including them. In the actual Bang, God conceives of all possible and impossible fully determinate attributes individuals and histories. ${ }^{99}$ Thus even on Leftow's picture 'there would have been the same secular states of affairs no matter what. ${ }^{, 100}$ Hence one could happily adopt Leftow's account of God's relation to necessity whilst adopting my solution to the Euthyphro dilemma, without arbitrariness worries over creatures goods. Thus, it seems that different answers can be given as to how definitional essences might be thought to depend upon God, where I have sketched out two options here. ${ }^{101}$

\section{The economical God}

I wish to finish this paper with one final reason why one might prefer the dispositional account of laws of nature and goodness over other accounts, namely due to simplicity. Simplicity is perhaps one of the most prized principles within modern ontology with Schaffer writing 'Do not multiply entities without necessity! Few principles are as pervasive in contemporary metaphysics.' 102 I follow Rodriguez-Pereya in thinking that there are two types of parsimony which are virtuous, quantitative and qualitative ontological economy. ${ }^{103}$ For our purposes, quantitative ontological economy concerns the creative steps God performs, and qualitative ontological economy refers to the number of entities other than God.

On the anti-realist view concerning laws of nature and goodness, God only creates substances. This is because there is no governing role for either physical laws or goodness, since both turn out to be human constructions. As such this view is quantitatively economic since God creates in one step, and qualitatively economic as there is only one entity, substances. As noted earlier, due to implications of subjectivity the majority of theists will reject this position. The Platonic view similarly has God creating in one step, making substances, and thus is likewise

\footnotetext{
98 See Leftow's magisterial God and Necessity for explication and defence of this view. Leftow (2012).

99 Leftow (2012, p. 369).

100 Leftow (2014, p. 450).

101 It should be noted that there hasn't as of yet been much work done within this area and so it isn't entirely clear which positions are available to someone holding my position and which are not. However, this is a place where some significant exploration is taking place, and Craig's recent work seems relevant here, where some of the options he discusses might be available for those who adopt my approach. However, exploring this in more detail is for further work. Craig (2016).

102 Other evidence for this is that having as few categories in one's ontology as possible is seen as virtuous (for instance see Paul's one category ontology), often at the expense of explanatory power. Within theistic debates Swinburne is perhaps the greatest advocate of simplicity as a guiding principle: Schaffer (2015, p. 644), Paul (2017), Swinburne (Swinburne 2004, pp. 52-66).

103 Rodriguez-Pereya (2002, pp. 204-210).
} 
quantitatively economical. However, there are three items within its ontology, eternal physical laws, eternal goods and substances, and therefore it is not qualitatively economical.

The two views theists can most plausibly choose between are SEG-DCT or the dispositionalist view. On SEG-DCT God creates in three steps, creating substances, laws, and goods, resulting in the view being neither quantitatively or qualitatively economical. By contrast, on the dispositionalist view God only creates substances with dispositional properties, since these endow the world with both laws of nature and goods. ${ }^{104}$ This position is therefore quantitatively and qualitatively economical which may give us further reason to prefer it to SEG-DCT. Perhaps one could mix and match positions to make an improved combination, e.g. the Humean position for laws and DCT for goods, however this would still mean that God creates in two steps, with two entities being created, substances and goods, and therefore is less quantitatively and qualitatively economical than the dispositionalist position. Even given the mixing and matching, plausibly the dispositionalist position still comes out best. Despite the virtue of parsimony providing one reason to adopt the dispositionalist view, we can also run a perfect being theology style argument, claiming as a perfection that God achieve all He desires with the least amount of creative steps, and with the least amount of ontology, what we might call being economical. Obviously if being economical is no perfection then one may not be persuaded that this gives further reason to prefer the dispositionalist position, but since I think being economical could be considered perfective then this gives us further reason to prefer this view. ${ }^{105}$

\section{Dis-positioning Euthyphro ${ }^{106}$}

I have suggested an alternative way the Euthyphro dilemma concerning goodness might be dissolved, providing theists with another way out. God doesn't will something because it is good, or command the goods of substances arbitrarily, as the horns of the Euthyphro dilemma would have us think. Rather, through creating dispositional properties the goods are determined, since they are the ends of these properties. Goods then are both in some sense determined by God, through His determining which dispositional essences are instantiated, and yet in another sense not, since the definitional essences of substances are broadly logically necessary. Interestingly the way I have suggested conceptualising physical laws and goods was historically overthrown by SEG and DCT, when the teleological/directedness view of nature fell out of favour. ${ }^{107}$ Perhaps then, with a rise in popularity of dispositionalist thinking and a renewed interest and respect for directionality and teleology, this old conception will once more become the prominent view, thereby

\footnotetext{
104 If we think of substances as bundles of dispositional properties then God only creates one thing, not both substances and dispositional properties.

105 Leibniz seems to have thought being economical was a perfection, see: Leibniz (1991, Section 22).

106 The 'dis' in dis-positioning refers to a Latin prefix meaning 'reversing force'.

107 Harrison (2015, pp. 15-16, 88-89).
} 
confirming the wisdom of Ecclesiastes 1:9 that 'there is nothing new under the sun.' (NRSV) This proposed solution to the problem then, will hopefully lend a helping hand to the theist in dis-positioning the Euthyphro dilemma as the king objection to theistic meta-ethics and also promote an alternative research project within this field.

Open Access This article is distributed under the terms of the Creative Commons Attribution 4.0 International License (http://creativecommons.org/licenses/by/4.0/), which permits unrestricted use, distribution, and reproduction in any medium, provided you give appropriate credit to the original author(s) and the source, provide a link to the Creative Commons license, and indicate if changes were made.

\section{References}

Adams, R. M. (1987). A modified divine command theory of ethical wrongness. In R. M. Adams (Ed.), The virtue of faith. New York: Oxford University Press.

Alexander, D. E. (2012). Goodness, god and evil. New York: Continuum.

Almotahari, M., \& Hosein, A. (2015). Is anything just plain good? Philosophical Studies, 172, 1485-1508.

Anjum, R. L., Lie, S. A. N., \& Mumford, S. (2013). Dispositions and ethics. In R. Groff \& J. Greco (Eds.), Powers and capacities in philosophy: The new aristotelianism. New York: Routledge.

Antony, L. (2009). Atheism as perfect piety. In R. K. Garcia \& N. L. King (Eds.), Is goodness without god good enough?. Lanham, MD: Rowman \& Littlefied.

Armstrong, D. M. (2010). Sketch for a systematic metaphysics. New York: Oxford University Press.

Baggett, D., \& Walls, J. L. (2011). Good god. New York: Oxford University Press.

Bauer, W. A. (2016). Physical intentionality, extrinsicness, and the direction of causation. Acta Analytica, 31, 397-417.

Beebee, H. (2000). The non-governing conception of the laws of nature. Philosophy and Phenomenological Research, 61, 571-594.

Bird, A. (2007). Nature's metaphysics. New York: Oxford University Press.

Black, R. (2000). Against quidditism. Australasian Journal of Philosophy, 78, 87-104.

Brink, D. O. (2007). The autonomy of ethics. In M. Martin (Ed.), Cambridge companion to atheism. New York: Cambridge University Press.

Brower, J. (2008). Making sense of divine simplicity. Faith and Philosophy, 25, 3-30.

Brower, J. E. (2014). Aquinas's ontology of the material world. New York: Oxford University Press.

Carroll, J. (1994). Laws of nature. Cambridge: Cambridge University Press.

Chakravartty, A. (2017). Saving the scientific phenomena: What powers can and cannot do. In J. Jacobs (Ed.), Causal powers. Oxford: Oxford University Press.

Chappell, T. (2004). The polymorphy of practical reason. In D. S. Oderberg \& T. Chappell (Eds.), Human values: New essays in natural law. New York: Palgrave Macmillan.

Copan, P. (2013). Ethics needs god. In J. P. Moreland, C. Meister, \& K. A. Sweis (Eds.), Debating Christian theism. New York: Oxford University Press.

Craig, W. L. (2008). Reasonable faith (3rd ed.). Wheaton, IL: Crossway Books.

Craig, W. L. (2016). God over all. New York: Oxford University Press.

Davies, B. (2004). An introduction to the philosophy of religion (3rd ed.). New York: Oxford University Press.

Davies, B. (2011). Thomas aquinas on god and evil. New York: Oxford University Press.

Dolezal, J. E. (2011). God without parts. Oregon: Pickwick Publications.

Ellis, B. (2001). Scientific essentialism. New York: Cambridge University Press.

Evans, S. C. (2013). God and moral obligation. New York: Oxford University Press.

Feser, E. (2010). Teleology: A Shopper's guide. Philosophia Christi, 12, 142-159.

Feser, E. (2013). Between Aristotle and William Paley: Aquinas's fifth way. Nova et Vetera, 11, 707-749.

Feser, E. (2014a). Scholastic metaphysics. Heusenstamm: Editiones Scholasticae.

Feser, E. (2014b). Being, the good, and the guise of the good. In D. Novotny \& L. Novak (Eds.), Neoaristotelian perspectives in metaphysics. London: Routledge. 
Feser, E. (2015). Classical natural law theory, property rights, and taxation. In E. Feser (Ed.), Neoscholastic essays. Indiana: St. Augustine's Press.

Fine, K. (1994). Essence and modality. Philosophical Perspectives, 8, 1-16.

Fine, K. (2005). The varieties of necessity. In K. Fine (Ed.), Modality and tense. New York: Oxford University Press.

Finnis, J. (2011). Natural law and natural rights (2nd ed.). New York: Oxford University Press.

Foot, P. (2001). Natural goodness. New York: Oxford University Press.

Geach, P. T. (1956). Good and evil. Analysis, 17, 33-42.

George, R. P. (1999). In defense of natural law. New York: Oxford University Press.

Gould, P. M. (2014). Beyond the control of god?. New York: Bloomsbury Academic.

Grayling, A. C. (2013). Critiques of theistic arguments. In S. Bullivant \& M. Ruse (Eds.), The Oxford handbook of atheism. New York: Oxford University Press.

Grisez, G. (1996). A contemporary natural law ethic. In G. F. McLean (Ed.), Normative ethics and objective reason. Washington: Council for Research in Values and Philosophy.

Groff, R., \& Greco, J. (2013). Powers and capacities in philosophy: The new aristotelianism. New York: Routledge.

Hacker, P. M. S. (2007). Human nature: The categorial framework. Oxford: Wiley.

Haldane, J. (2002). Mind metaphysics and value in the thomistic and analytical traditions. Notre Dame, IN: University of Notre Dame Press.

Harris, H. (2011). Introduction. In H. Harris (Ed.), God, goodness and philosophy. Farnham: Ashgate Publishing.

Harrison, P. (2015). The territories of science and religion. Chicago: University of Chicago Press.

Hart, D. B. (2013). The experience of god. Michigan: Yale University Press.

Hawthorne, J., \& Nolan, J. (2006). What would teleological causation be? In J. Hawthorne (Ed.), Metaphysical essays. New York: Oxford University Press.

Heil, J. (2003). From and ontological point of view. New York: Oxford University Press.

Hoffman, P. (2009). Does efficient causation presuppose final causation? In S. Newlands \& L. M. Jorgensen (Eds.), Metaphysics and the good. New York: Oxford University Press.

Idziak, J. M. (2004). Reply to Boyd and VanArragon. In M. L. Peterson \& R. J. VanArragon (Eds.), Contemporary debates in philosophy of religion. Oxford: Wiley.

Jacobs, J. (2017). Causal powers. Oxford: Oxford University Press.

Jordan, M. C. (2013). Divine commands or divine attitudes? Faith and Philosophy, 30, 159-170.

Koons, J. (2012). Can God's goodness save the divine command theory from euthyphro? European Journal for Philosophy of Religion, 4, 177-195.

Kretzmann, N. J. (1999). Abraham, issac and euthyphro: God and the basis of morality. In E. Stump \& M. J. Murray (Eds.), Philosophy of religion: The big questions. Oxford: Wiley.

Kripke, S. (1972). Naming and necessity. Oxford: Wiley.

Kroll, N. (2017). Teleological dispositions. Oxford Studies in Metaphysics, 10, 3-37.

Lange, M. (2000). Natural laws in scientific practice. Oxford: Oxford University Press.

Leftow, B. (2006). God and the problem of universals. Oxford Studies in Metaphysics, 2, 325-356.

Leftow, B. (2012). God and necessity. New York: Oxford University Press.

Leftow, B. (2014). On god and necessity. Faith and Philosophy, 31, 435-459.

Leibniz, W. G. (1991). Discourse on metaphysics and other essays (D. Garber \& R. Ariew, Trans.). Indiana: Hackett Publishing Company.

Lisska, A. (1996). Aquinas's theory of natural law: An analytic reconstruction. New York: Oxford University Press.

Loewer, B. (1996). Humean supervenience. Philosophical Topics, 24, 101-127.

Lowe, E. J. (1989). Kinds of being. Oxford: Wiley.

Lowe, E. J. (2008). Two notions of being: Entity and essence. Royal Institute of Philosophy Supplement, 62, 23-48.

MacDonald, S. (1991). Being and goodness. Ithaca: Cornell University Press.

Mackie, J. L. (1982). The miracle of theism. New York: Oxford University Press.

Mann, W. E. (2015). God, modality and morality. New York: Oxford University Press.

Marmodoro, A. (2010). The metaphysics of powers. New York: Routledge.

Martin, C. B. (2007). The mind in nature. New York: Oxford University Press.

McGrath, A. E. (2011). Darwinism and the divine. Oxford: Wiley.

McGrath, M. (Spring 2014 Edition). Propositions. In E. N. Zalta (Ed.), The stanford encyclopedia of philosophy. https://plato.stanford.edu/archives/spr2014/entries/propositions/. 
Miller, C. (2009). Divine desire theory and obligation. In Y. Nagasawa \& E. Wielenberg (Eds.), New waves in philosophy of religion. New York: Palgrave Macmillan.

Miller, C. (2013) The Euthyphro dilemma. In Hugh LaFollette (Ed.), The Blackwell international encyclopedia of ethics. Oxford: Blackwell Publishing.

Millken, J. (2009). Euthyphro, the good, and the right. Philosophica Christi, 11, 149-159.

Molnar, G. (2003). Powers. New York: Oxford University Press.

Mumford, S. (1998). Dispositions. New York: Oxford University Press.

Mumford, S. (2004). Laws in nature. New York: Routledge.

Murphy, M. C. (1998). Divine command, divine will, and moral obligation. Faith and Philosophy, 15, 3-27.

Murphy, M. C. (2011). God and moral law. New York: Oxford University Press.

Nagel, T. (2012). Mind and Cosmos. New York: Oxford University Press.

Novotný, D. D., \& Novák, L. (2014). Neo-aristotelian perspectives in metaphysics. New York: Routledge.

Oderberg, D. S. (2000). Moral theory (pp. 1-39). Oxford: Wiley.

Oderberg, D. S. (2001). How to win essence back from essentialists. Philosophical Writings, 18, $27-45$.

Oderberg, D. S. (2007). Real essentialism. New York: Routledge.

Oderberg, D. S. (2008). Teleology: Inorganic and organic. In A. M. González (Ed.), Contemporary perspectives on natural law. Aldershot: Ashgate.

Oderberg, D. S. (2010). Metaphysical foundations of natural law. In H. Zaborowski (Ed.), Natural moral law in contemporary society. Washington, DC: Catholic University of America Press.

Oderberg, D. S. (2014). Being and goodness. American Philosophical Quarterly, 51, 345-356.

Oderberg, D. S. (2016). Finality revived: Powers and intentionality. Synthese doi:10.1007/s11229-0161057-5.

Oderberg, D. S. (forthcoming). The metaphysics of good and evil.

Oppy, G. (2006). Arguing about gods. New York: Cambridge University Press.

Page, B. (2015). The dispositionalist deity: How god creates laws and why theists should care. Zygon, 50, 113-137.

Page, B. (forthcoming). Fine-tuned of necessity.

Paterson, C., \& Pugh, M. S. (2006). Analytical thomism. Aldershot: Ashgate Publishing.

Paul, L. A. (2017). A one category ontology. In J. A. Keller (Ed.), Freedom, metaphysics, and method: Themes from van Inwagen. New York: Oxford University Press.

Peterson, J. (1999). Introduction to scholastic realism. New York: Peter Lang.

Pigliucci, M. (2013). New atheism and the scientistic turn in the atheism movement. Midwest Studies in Philosophy, 371, 42-153.

Place, U. T. (1996). Intentionality as the mark of the dispositional. Dialectica, 50, 91-120.

Plantinga, A. (1980). Does god have a nature?. Milwaukee: Marquette University Press.

Pope, S. J. (2012). Natural law and Christian ethics. In R. Gill (Ed.), The Cambridge companion to Christian ethics (2nd ed.). New York: Cambridge University Press.

Quinn, P. (2001). Divine command theory. In H. LaFollette (Ed.), Blackwell guide to ethical theory. Oxford: Wiley.

Quinn, P. L. (2006). Theological voluntarism. In D. Copp (Ed.), The Oxford handbook of ethical theory. New York: Oxford University Press.

Robinson, L. (2011). Moral principles as moral dispositions. Philosophical Studies, 156, 289-309.

Rodriguez-Pereya, G. (2002). Resemblance nominalism: A solution to the problem of universals. New York: Oxford University Press.

Rooney, J. D. (2013). Evolutionary biology and classical teleological arguments for god's existence. The Heythrop Journal, 54, 617-630.

Ruse, M. (2015). Atheism: What everyone needs to know. New York: Oxford University Press.

Schaffer, J. (2015). What not to multiply without necessity. Australasian Journal of Philosophy, 93, 644-664.

Shoemaker, S. (1980). Causality and properties. In P. van Inwagen (Ed.), Time and cause. Dordrecht: D. Reidel.

Simpson, W. M. R., Koons, R. C., \& The, N. J. (2017). Neo-aristotelian perspectives on contemporary science. New York: Routledge.

Sinnott-Armstrong, W. (2009). Why traditional theism cannot provide an adequate foundation for morality. In R. K. Garcia \& N. L. King (Eds.), Is goodness without god good enough?. Lanham, MD: Rowman \& Littlefied. 
Smith, M., Lewis, D., \& Johnston, M. (1989). Dispositional theories of value. Proceedings of the Aristotelian Society, Supplementary, 63, 89-174.

Stump, E. (2003). Aquinas. New York: Routledge.

Stump, E. (2010). Wandering in darkness. New York: Oxford University Press.

Swinburne, R. (2004). The existence of god (2nd ed.). New York: Oxford University Press.

Swinburne, R. (2016). The coherence of theism (2nd ed.). London: Oxford University Press.

Tahko, T. E. (2012). Contemporary aristotelian metaphysics. New York: Cambridge University Press. Teichmann, R. (2011). Nature, reason \& the good life. New York: Oxford University Press. Vetter, B. (2015). Potentiality. New York: Oxford University Press.

Walsh, D. (2006). Evolutionary essentialism. British Journal of Philosophy of Science, 57, 425-448.

Walsh, D. (2015). Organisms. Cambridge: Cambridge University Press.

Ward, K. (2013). Morality, autonomy, and god. London: Oneworld.

Welty, G. (2014). Theistic Conceptual Realism. In P. M. Gould (Ed.), Beyond the control of God?. New York: Bloomsbury Academic.

Wielenberg, E. J. (2013). Atheism and morality. In S. Bullivant \& M. Ruse (Eds.), The Oxford handbook of atheism. New York: Oxford University Press.

Wierenga, E. R. (1989). The nature of god. New York: Cornell University Press.

Aristotle. Nicomachean ethics.

Zagzebski, L. (2004). Divine motivation theory. Cambridge: Cambridge University Press.

Zagzebski, L. (2005). Morality and religion. In W. J. Wainwright (Ed.), The Oxford handbook of philosophy of religion. New York: Oxford University Press. 